\author{
Monika Borowiec \\ Zakład Przedsiębiorczości i Gospodarki Przestrzennej \\ Instytut Geografii \\ Uniwersytet Pedagogiczny im. KEN w Krakowie
}

\title{
Rola edukacji w ksztaltowaniu społeczeństwa informacyjnego
}

Cywilizacja informacyjna jest cywilizacją szybkich zmian, co oznacza konieczność reagowania na nowe uwarunkowania, a podstawowym czynnikiem jej rozwoju są zasoby kapitału ludzkiego, którego jakość jest kształtowana w procesie edukacyjnym. Współcześnie informacja staje się najcenniejszym dobrem każdej instytucji, organizacji, przedsiębiorstwa, jednostki, co powoduje dynamiczny rozwój technologii umożliwiających jej pozyskiwanie, przesyłanie $\mathrm{i}$ analizę (Nowak 2005). Bardzo szybki rozwój telefonii komórkowej i upowszechnienie dostępu do internetu umożliwia i przyspiesza komunikację oraz dostęp do informacji na bardzo szeroką skalę. Należy jednak podkreślić, że ,społeczeństwo informacyjne będzie na tyle konkurencyjne, na ile jego gospodarka zostanie oparta na wiedzy. Kluczem do wiedzy jest edukacja. Dlatego wykształcenie społeczeństwa nie może być traktowane wyłącznie jako indywidualna sprawa uczącego się, tylko jako strategiczne zadanie dla państwa" (Abramowicz 2002, s. 121).

Pierwsze wzmianki na temat społeczeństwa informacyjnego pojawiły się już w połowie lat 60. XX w. w Japonii, gdzie rozwój mikroelektroniki będącej podstawą techniki cyfrowej był najszybszy. Od tego czasu ukazało się bardzo wiele różnych publikacji dotyczących społeczeństwa i programów mających na celu przyspieszenie jego rozwoju, zwłaszcza w krajach wysoko rozwiniętych. Za J.S. Nowakiem (2005, s. 1-5) przedstawiamy kilka spośród wielu prób zdefiniowania społeczeństwa informacyjnego:

- „Społeczeństwo informacyjne jako społeczeństwo, w którym informacja jest kluczowym elementem społeczno-ekonomicznej działalności i zmian” (Casey 2001).

- „Społeczeństwo charakteryzujące się przygotowaniem i zdolnością do użytkowania systemów informatycznych, skomputeryzowane i wykorzystujące usługi telekomunikacji do przesyłania i zdalnego przetwarzania informacji” (I Kongres Informatyki Polskiej, 1994).

- „Społeczeństwo informacyjne to społeczeństwo, które nie tylko posiada rozwinięte środki przetwarzania informacji i komunikowania, lecz środki te są podstawą tworzenia dochodu narodowego i dostarczają źródła utrzymania większości społeczeństwa" (Goban-Klas, Sienkiewicz 1999).

- „Społeczeństwo informacyjne [ang. information society] - nowy system społeczeństwa kształtujący się w krajach o wysokim stopniu rozwoju technologicznego, gdzie zarządzanie informacją, jej jakość, szybkość przepływu są zasadniczymi czynnikami konkurencyjności zarówno w przemyśle, jak i w usługach, a stopień rozwoju wymaga stosowania nowych technik gromadzenia, przetwarzania, przekazywania i użytkowania informacji” (Ministerstwo Łączności RP, 2001).

- Według Urzędu Komitetu Integracji Europejskiej „Społeczeństwo informacyjne to nowy typ społeczeństwa, który ukształtował się w krajach, w których rozwój nowoczesnych tech- 
nologii teleinformatycznych osiągnął bardzo szybkie tempo. Podstawowymi warunkami, które muszą być spełnione, aby społeczeństwo można było uznać za informacyjne, jest rozbudowana nowoczesna sieć telekomunikacyjna, która swoim zasięgiem obejmowałaby wszystkich obywateli oraz rozbudowane zasoby informacyjne dostępne publicznie. Ważnym aspektem jest również kształcenie społeczeństwa w kierunku dalszego rozwoju, tak by wszyscy mogli w pełni wykorzystywać możliwości, jakie dają środki masowej komunikacji i informacji".

Definicje społeczeństwa informacyjnego są zatem wieloaspektowe (Długosz 2003). Rozpatrują społeczeństwo m.in. w aspekcie technologicznym, czyli jako kreowane przez internet $\mathrm{i}$ jego możliwości, w aspekcie ekonomicznym, kiedy zwraca się uwagę na przetwarzanie informacji jako podstawę tworzenia dochodu narodowego i źródło utrzymania dla większości społeczeństwa, lub w aspekcie demokratycznym, kiedy zwraca się uwagę na społeczeństwo poinformowane, gdzie każdy ma prawo do informowania i bycia informowanym. Jednakże wielu badaczy naczelne znaczenie przypisuje w nim nie tylko informacji, ale także wiedzy, określając je jako społeczeństwo wiedzy.

Główne cechy społeczeństwa informacyjnego zostały sformułowane przez Daniela Bella w 1973 r. (Nowak 2005). Wskazuje on na cechy społeczeństwa informacyjnego, takie jak:

- dominacja sektora usług w gospodarce,

- rosnące znaczenie specjalistów i naukowców w strukturze zawodowej,

- dominujące znaczenie wiedzy teoretycznej jako źródła innowacji,

- nastawienie na rozwój określonych dziedzin techniki,

- tworzenie nowych, „technologii intelektualnych” jako podstaw podejmowania decyzji politycznych i społecznych.

Współcześnie najważniejszym dokumentem programowym Unii Europejskiej w zakresie społeczeństwa informacyjnego, zatwierdzonym w 2004 r., jest i2010 - Europejskie spoleczeństwo informacyjne na rzecz wzrostu i zatrudnienia ${ }^{1}$. Dokument ten wpisuje się w ramy strategiczne wyznaczone w 2000 r. przez Strategię Lizbońską, która wśród pięciu obszarów działania wymienia dążenie do rozwoju gospodarki opartej na wiedzy - budowę społeczeństwa informacyjnego oraz zwiększenie nakładów na badania i rozwój. Stanowi on jednocześnie kontynuację pierwszego programu realizującego założenia Strategii Lizbońskiej - eEurope 2005.

W Polsce zadania $\mathrm{w}$ zakresie informatyzacji oraz rozwoju społeczeństwa informacyjnego do 2006 r. zostały wyznaczone w Strategii informatyzacji Rzeczypospolitej Polskiej-ePolska na lata 2004-2006, przyjętej przez Radę Ministrów 13 stycznia 2004 r. Strategia kierunkowa rozwoju informatyzacji Polski w latach 2007-2013 oraz perspektywiczna prognoza transformacji społeczeństwa informacyjnego do roku 2020 stanowią prognozę na okres po zakończeniu obowiązywania Strategii ePolska.

Cele procesu informatyzacji Polski w perspektywie roku 2013 obejmują:

1. zlikwidowanie zjawiska „wykluczenia cyfrowego" w zagrożonych grupach społecznych i obszarach geograficznych;

2. zwiększenie dostępu do szerokopasmowego internetu do poziomu ponad $90 \%$ powierzchni kraju i co najmniej $75 \%$ populacji;

3. wzmocnienie infrastruktury teleinformatycznej nauki, umożliwiające aktywne uczestnictwo wszystkich jednostek naukowych w nowych formach aktywności;

4. stworzenie wewnętrznej, bezpiecznej sieci administracji publicznej, docierającej do wszystkich jednostek administracji w całym kraju;

${ }^{1}$ Kierunki rozwoju społeczeństwa informacyjnego w Małopolsce w latach 2007-2010, Urząd Marszałkowski Województwa Małopolskiego, Kraków 2007. 
5. stworzenie ogólnokrajowych, wielokanałowych zintegrowanych platform świadczenia usług elektronicznych administracji, wykorzystujących podpis cyfrowy i identyfikator elektroniczny, w tym platform usług specjalizowanych (jak eTurystyka, eTransport);

6. wdrożenie systemu identyfikacji obywatela, opartego na wielofunkcyjnych dokumentach osobistych; stworzenie warunków do uruchomienia systemów e-demokracji;

7. zapewnienie bezpiecznego i skutecznego dostępu online do wszystkich rejestrów państwowych i systemów ewidencyjnych administracji publicznej;

8. zwiększenie dostępności do systemu usług elektronicznych w Polsce, świadczonych zarówno przez sektor publiczny, jak i prywatny, do poziomu co najmniej $80 \%$, a w przypadku administracji - do 100\% usług świadczonych online;

9. osiągnięcie 95-procentowego wskaźnika dostępności i 90-procentowego wskaźnika nasycenia dla telewizji cyfrowej;

10. zwiększenie dostępności polskich zasobów cyfrowych w wersji wielojęzycznej w internecie - minimum $80 \%$ zasobów dostępnych dodatkowo w przynajmniej jednym języku oficjalnym Unii Europejskiej (obok polskiego);

11. stworzenie warunków dla rozpowszechnienia edukacji teleinformatycznej.

Wspomniane wcześniej liczne definicje społeczeństwa informacyjnego wskazują na wiodącą rolę dostępu do informacji. Należy jednak podkreślić, że dostęp do informacji nie jest gwarantem dobrego funkcjonowania w społeczeństwie informacyjnym, ponieważ szczególnie istotna jest umiejętność oceny wartości informacji, jej selekcji i analizy (Długosz 2003). „Niekontrolowana i niezorganizowana informacja nie jest bogactwem w społeczeństwie informacyjnym, lecz przeciwnie, staje się wrogiem pracownika zajmującego się informacją. Naukowcy, którzy są przytłoczeni danymi technicznymi, narzekają na szum informacyjny; twierdzą, że mniej czasu potrzeba im na przeprowadzenie doświadczenia niż na wyszukanie informacji, czy wcześniej zostało ono przeprowadzone, czy też nie” (Naisbitt 1997, s. 44 i 45 [za:] Majta 2003).

Bardzo często kompetencje użytkownika są niewystarczające do określenia znaczenia i prawdziwości informacji, a ocena ta ma kluczowe znaczenie w podejmowaniu decyzji o jej wykorzystaniu. Szczególnie ważne jest rozwijanie umiejętności selekcji informacji, zarówno na poziomie jednostki czy grupy, jak i społeczeństwa. W sprawnym funkcjonowaniu w społeczeństwie informacyjnym istotne znaczenie ma zatem edukacja na wszystkich poziomach, kształtująca kompetencje i przygotowująca młodego człowieka do skutecznego wykorzystywania informacji, pogłębiania wiedzy i kształcenia ustawicznego. Podnoszenie jakości kapitału ludzkiego dokonujące się w wyniku kształcenia na wszystkich poziomach edukacji jest ważnym czynnikiem zabezpieczającym przed wykluczeniem informacyjnym.

Należy podkreślić, że wraz z rozwojem społeczeństwa informacyjnego, w przestrzeni światowej nasilają się procesy polaryzacyjne i pojawia się grupa ludności wykluczonej, czyli pozbawionej dostępu do szeroko pojętej technologii informacyjnej i umiejętności korzystania z niej. W konsekwencji niedoinformowani i niewykształceni ludzie są bardziej narażeni na bezrobocie, stają się coraz bardziej „odcięci” i mają ograniczony wkład w funkcjonowanie społeczeństwa informacyjnego (Długosz 2003).

Na znaczne zróżnicowanie przestrzeni światowej w zakresie informatyzacji wskazują m.in. wartości wskaźników: ,abonenci telefonii komórkowej na 100 mieszkańców” - od 21,6\% w Afryce do 94,3\% w Europie, ,abonenci łączy internetowych na 100 mieszkańców” - od 1,3\% w Afryce do 29,3\% w Australii i Oceanii oraz ,abonenci internetu szerokopasmowego na 100 mieszkańców" - od 0,1\% w Afryce do 13,7\% w Australii i Oceanii (tab. 1). 
Tab. 1. Telefonia stacjonarna i komórkowa oraz internet na świecie w $2006 \mathrm{r}$.

\begin{tabular}{|l|c|c|c|c|}
\hline \multirow{2}{*}{ Kontynenty } & $\begin{array}{c}\text { Abonenci } \\
\text { telefonii } \\
\text { komórkowej }\end{array}$ & $\begin{array}{c}\text { Abonenci lączy } \\
\text { internetowych }\end{array}$ & $\begin{array}{c}\text { Abonenci internetu } \\
\text { szerokopasmowego }\end{array}$ & $\begin{array}{c}\text { Stale linie } \\
\text { telefoniczne } \\
\text { (lącza główne) }\end{array}$ \\
\cline { 2 - 5 } Śmiat & \multicolumn{4}{|c|}{ na 100 mieszkańców } \\
\hline Afryka & $\mathbf{4 1 , 1}$ & $\mathbf{6 , 7}$ & $\mathbf{4 , 3}$ & $\mathbf{1 9 , 4}$ \\
\hline $\begin{array}{l}\text { Ameryka Północna } \\
\text { i Ameryka Południowa }\end{array}$ & 21,6 & 1,3 & 0,1 & 3,1 \\
\hline Azja & 62,0 & 11,4 & 8,9 & 32,4 \\
\hline Europa & 29,3 & 4,8 & 2,7 & 15,8 \\
\hline Australia i Oceania & 94,3 & 15,2 & 11 & 39,7 \\
\hline
\end{tabular}

Źródło: opracowanie autorki na podstawie Społeczeństwo informacyjne w Polsce. Wyniki badań statystycznych z lat 2004-2006, GUS, Warszawa 2008.

Rosnąca w szybkim tempie ilość informacji, ciągłość zmian, nowe techniki komunikacyjne, rosnąca mobilność ludzi - zwiększają zapotrzebowanie na wiedzę. Nowe techniki informacyjne przyczyniają się do zmian w systemie edukacji. Pojawiają się nowe metody dostępu uczniów i nauczycieli do informacji, a rozwój technik informacyjnych znacząco zmienia możliwości przekazu. Ponadto, nowe techniki informacyjne z czasem staną się bardziej istotnym przedmiotem nauczania, aby przygotowywać przyszłych pracowników do wykorzystywania oprzyrządowania informatycznego. Szczególne znaczenie ma kształcenie na kierunkach informatycznych.

W Polsce w latach 2000-2006 trzyipółkrotnie zwiększyła się liczba absolwentów kierunków informatycznych na studiach magisterskich i zawodowych. W przypadku uczelni państwowych liczba studentów kończących takie kierunki wzrosła nawet pięciokrotnie $-\mathrm{z}$ niecałych 2 tys. do 10 tys. (Społeczeństwo informacyjne w Polsce, 2008). W latach 2004-2006 liczba absolwentów kierunku informatycznego na studiach magisterskich i zawodowych wzrosła o połowę - z 9,2 do 14,0 tys., a kierunku informatyka i ekonometria utrzymała się na zbliżonym do niego poziomie (3,2 tys.).

W latach 2001-2005 wartość wskaźnika „absolwenci szkół wyższych państwowych lub prywatnych w zakresie technologii teleinformatycznych w wieku 20-29 lat na 1000 osób" wzrosła z 7,6 do 11,1 (ryc. 1).

Ryc. 1. Liczba absolwentów szkół wyższych kierunków teleinformatycznych w przeliczeniu na 1000 osób w wieku 20-29 lat w państwach europejskich w 2005 r.

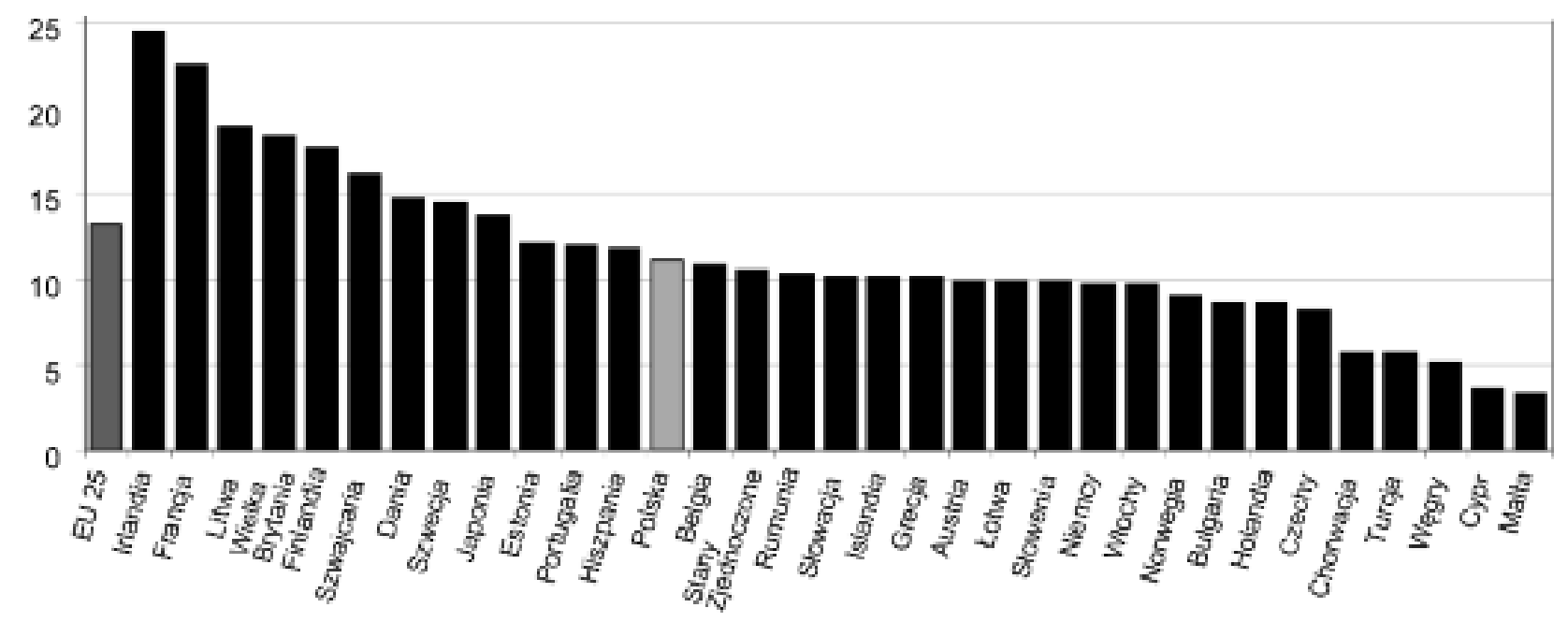

Źródło: opracowanie autorki na podstawie Eurostatu. 
Wskaźnik ten dla Polski był zatem wyższy niż w takich potęgach gospodarczych, jak Stany Zjednoczone $(10,6)$, Niemcy $(9,7)$, Norwegia $(9,0)$ czy Holandia $(8,6)$, lecz niższy od średniej dla 25 krajów członkowskich UE $(13,2)$. Najwyższymi wartościami wskaźnika (powyżej 15) odznaczały się Irlandia, Francja, Litwa, Wielka Brytania, Finlandia i Szwajcaria, a najniższymi (poniżej 7) - Malta, Cypr, Węgry, Turcja, Chorwacja.

Kształcenie na kierunkach informatycznych ma wpływ na poziom umiejętności komputerowych, który warunkuje możliwości rozwoju społeczeństwa informacyjnego. Poziom umiejętności komputerowych w państwach Unii Europejskiej (UE) jest bardzo zróżnicowany. Średni udział osób o wysokim poziomie tych umiejętności wynosi 23\% i waha się od 39\% w Luksemburgu do 5\% w Rumunii (ryc. 2).

Ryc. 2. Udział ludności o wysokim poziomie umiejętności komputerowych w ogólnej liczbie ludności w wieku 16-74 lat w 2006 r.

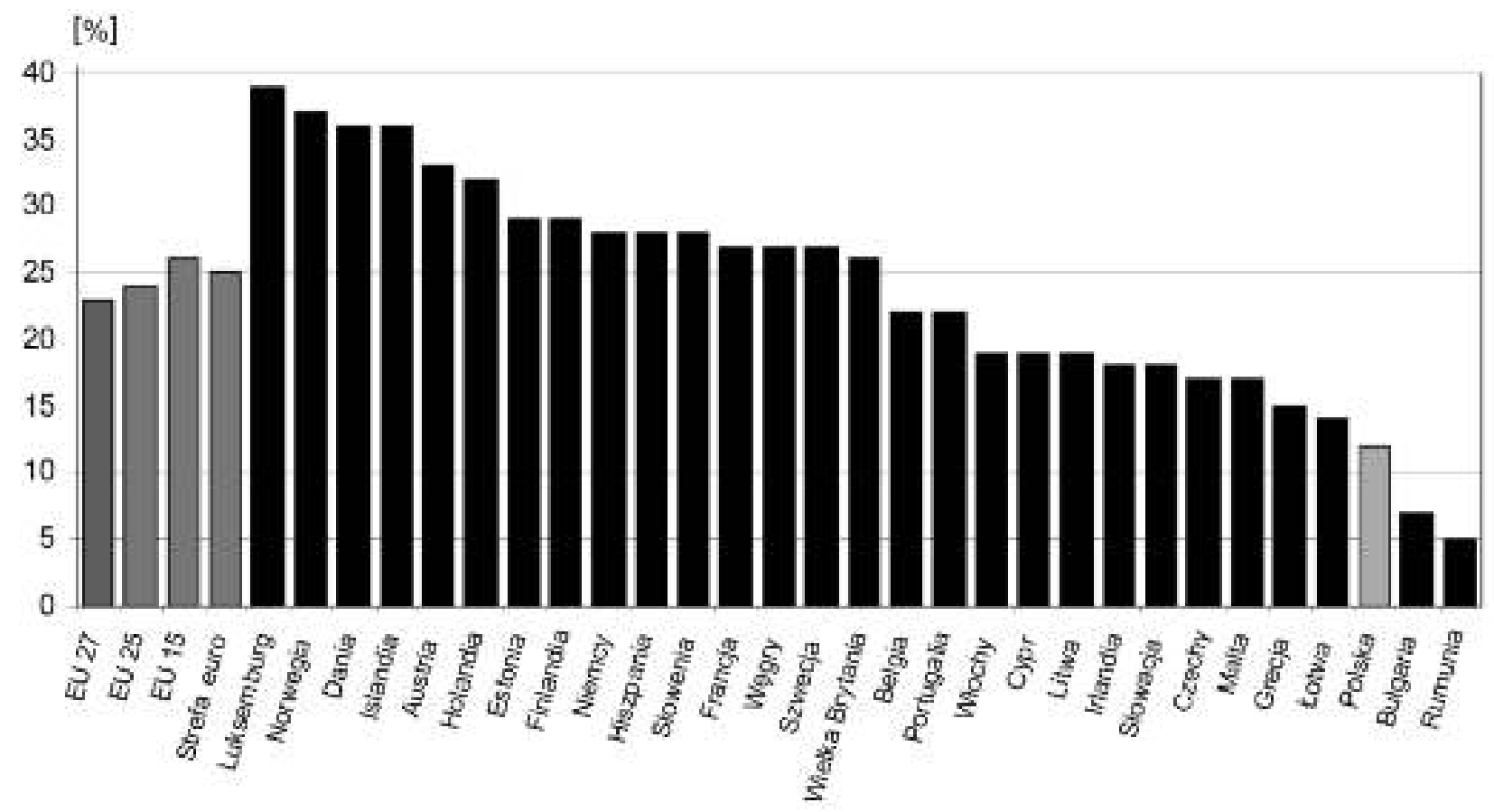

Źródło: opracowanie autorki na podstawie Eurostatu.

Wysokim udziałem - powyżej 30\% - odznaczają się również Dania, Austria i Holandia, a najniższym (poniżej 15\%) - Bułgaria, Polska, Łotwa, Grecja.

W procesie kształtowania społeczeństwa, oprócz umiejętności informatycznych, duże znacznie ma dostępność do największego źródła informacji - internetu. Dostęp do internetu w państwach Unii Europejskiej systematycznie wzrasta. Udział gospodarstw mających w domu dostęp do internetu w państwach UE w ciągu tylko trzech lat 2004-2007 zwiększył się z 40\% do 54\%, czyli o 14 pp. (tab. 2). W Polsce ten udział jest niższy od średniej dla UE, ale w latach 2002-2007 znacznie wzrósł - z 11\% do 41\%, czyli o 30 pp. W tym okresie największy wzrost udziału gospodarstw mających dostęp do internetu zaznaczył się na Łotwie (o 48 pp.), na Litwie (o 40 pp.), w Luksemburgu (o 35 pp.) i w Austrii (o 27 pp.).W 2007 r. ten udział wahał się od 83\% w Holandii do 19\% w Bułgarii (ryc. 3). Wysokim udziałem - powyżej 70\% - odznaczają się również Szwecja, Dania, Luksemburg i Niemcy. Niski udział - poniżej 40\% - mają Rumunia, Grecja, Czechy, Węgry, Cypr i Portugalia. 
Tab. 2. Zmiany udziału gospodarstw domowych mających dostęp do internetu i osób korzystających w domu $z$ internetu

\begin{tabular}{|c|c|c|c|c|c|c|c|c|c|c|c|c|}
\hline \multirow[t]{2}{*}{ Państwa } & \multicolumn{6}{|c|}{$\begin{array}{l}\text { Udzial gospodarstw domowych } \\
\text { mających dostęp do internetu }\end{array}$} & \multicolumn{6}{|c|}{$\begin{array}{l}\text { Udział osób w wieku 16-74 lata } \\
\text { w ogólnej liczbie ludności } \\
\text { korzystającej w domu z internetu }\end{array}$} \\
\hline & 2002 & 2003 & 2004 & 2005 & 2006 & 2007 & 2002 & 2003 & 2004 & 2005 & 2006 & 2007 \\
\hline EU-15 & 39 & 43 & 45 & 53 & 54 & 59 & 31 & 37 & 39 & 44 & 45 & 51 \\
\hline EU-25 & - & - & 42 & 48 & 51 & 56 & - & - & 34 & 40 & 43 & 49 \\
\hline EU-27 & - & - & 40 & 48 & 49 & 54 & - & - & 32 & 40 & 41 & 47 \\
\hline Strefa euro & 36 & 40 & 43 & 50 & 51 & 56 & 26 & 33 & 34 & 40 & 42 & 48 \\
\hline Austria & 33 & 37 & 45 & 47 & 52 & 60 & 23 & 30 & 37 & 41 & 47 & 55 \\
\hline Belgia & - & - & - & 50 & 54 & 60 & - & - & - & 47 & 53 & 60 \\
\hline Bułgaria & - & - & 10 & - & 17 & 19 & - & - & 7 & - & 14 & 22 \\
\hline Cypr & 24 & 29 & 53 & 32 & 37 & 39 & - & - & 22 & 22 & 24 & 27 \\
\hline Dania & 56 & 64 & 69 & 75 & 79 & 78 & 49 & 63 & 68 & 72 & 77 & 77 \\
\hline Estonia & - & - & 31 & 39 & 46 & 53 & - & - & 32 & 40 & 46 & 53 \\
\hline Finlandia & 44 & 47 & 51 & 54 & 65 & 69 & 41 & 45 & 49 & 56 & 65 & 70 \\
\hline Francja & 23 & 31 & 34 & - & 41 & 49 & - & - & - & - & 35 & 46 \\
\hline Grecja & 12 & 16 & 17 & 22 & 23 & 25 & 8 & 10 & 12 & 14 & 18 & 21 \\
\hline Hiszpania & - & 28 & 34 & 36 & 39 & 45 & 14 & 22 & 26 & 28 & 33 & 38 \\
\hline Holandia & 58 & 61 & - & 78 & 80 & 83 & - & 56 & - & 74 & 77 & 82 \\
\hline Irlandia & - & 36 & 40 & 47 & 50 & 57 & - & 21 & 22 & 26 & 36 & 44 \\
\hline Islandia & - & - & 81 & 84 & 83 & 84 & - & 69 & 65 & 77 & 80 & 84 \\
\hline Litwa & 4 & 6 & 12 & 16 & 35 & 44 & - & 7 & 11 & 16 & 29 & 39 \\
\hline Luksemburg & 40 & 45 & 59 & 65 & 70 & 75 & 32 & 43 & 59 & 65 & 65 & 72 \\
\hline Łotwa & 3 & - & 15 & 31 & 42 & 51 & - & - & 11 & 21 & 31 & 43 \\
\hline Macedonia & - & - & 11 & - & 14 & - & - & - & 8 & - & 8 & - \\
\hline Malta & - & - & - & 41 & 53 & 54 & - & - & - & 30 & 32 & 42 \\
\hline Niemcy & 46 & 54 & 60 & 62 & 67 & 71 & 39 & 45 & 52 & 57 & 61 & 64 \\
\hline Norwegia & - & 60 & 60 & 64 & 69 & 78 & - & 60 & 62 & 67 & 73 & 79 \\
\hline Polska & 11 & 14 & 26 & 30 & 36 & 41 & - & - & 15 & 20 & 26 & 33 \\
\hline Portugalia & 15 & 22 & 26 & 31 & 35 & 40 & 12 & 15 & 17 & 20 & 23 & 27 \\
\hline Czechy & - & 15 & 19 & 19 & 29 & 35 & - & 17 & 20 & 20 & 31 & 37 \\
\hline Rumunia & - & - & 6 & - & 14 & 22 & - & - & 5 & - & 11 & 16 \\
\hline Słowacja & - & - & 23 & 23 & 27 & 46 & - & - & 22 & 20 & 24 & 34 \\
\hline Słowenia & - & - & 47 & 48 & 54 & 58 & - & - & 26 & 35 & 41 & 45 \\
\hline Szwecja & - & - & - & 73 & 77 & 79 & 59 & 65 & 69 & 71 & 77 & 73 \\
\hline Turcja & - & - & 7 & 8 & - & - & - & - & 4 & 4 & - & - \\
\hline Węgry & - & - & 14 & 22 & 32 & 38 & - & - & 14 & 21 & 29 & 38 \\
\hline Wielka Brytania & 50 & 55 & 56 & 60 & 63 & 67 & 44 & 50 & 51 & 55 & 55 & 62 \\
\hline Włochy & 34 & 32 & 34 & 39 & 40 & 43 & 20 & 23 & 21 & 24 & 27 & 30 \\
\hline Japonia & 49 & 54 & 56 & 57 & - & - & - & - & - & - & - & - \\
\hline Kanada & 51 & 55 & 60 & 61 & - & - & - & - & - & - & - & - \\
\hline Stany Zjedn. & - & 55 & - & - & - & - & - & - & - & - & - & - \\
\hline
\end{tabular}

Źródło: opracowanie autorki na podstawie Eurostatu. 
Ryc. 3. Udział gospodarstw domowych mających dostęp do internetu w 2007 r.

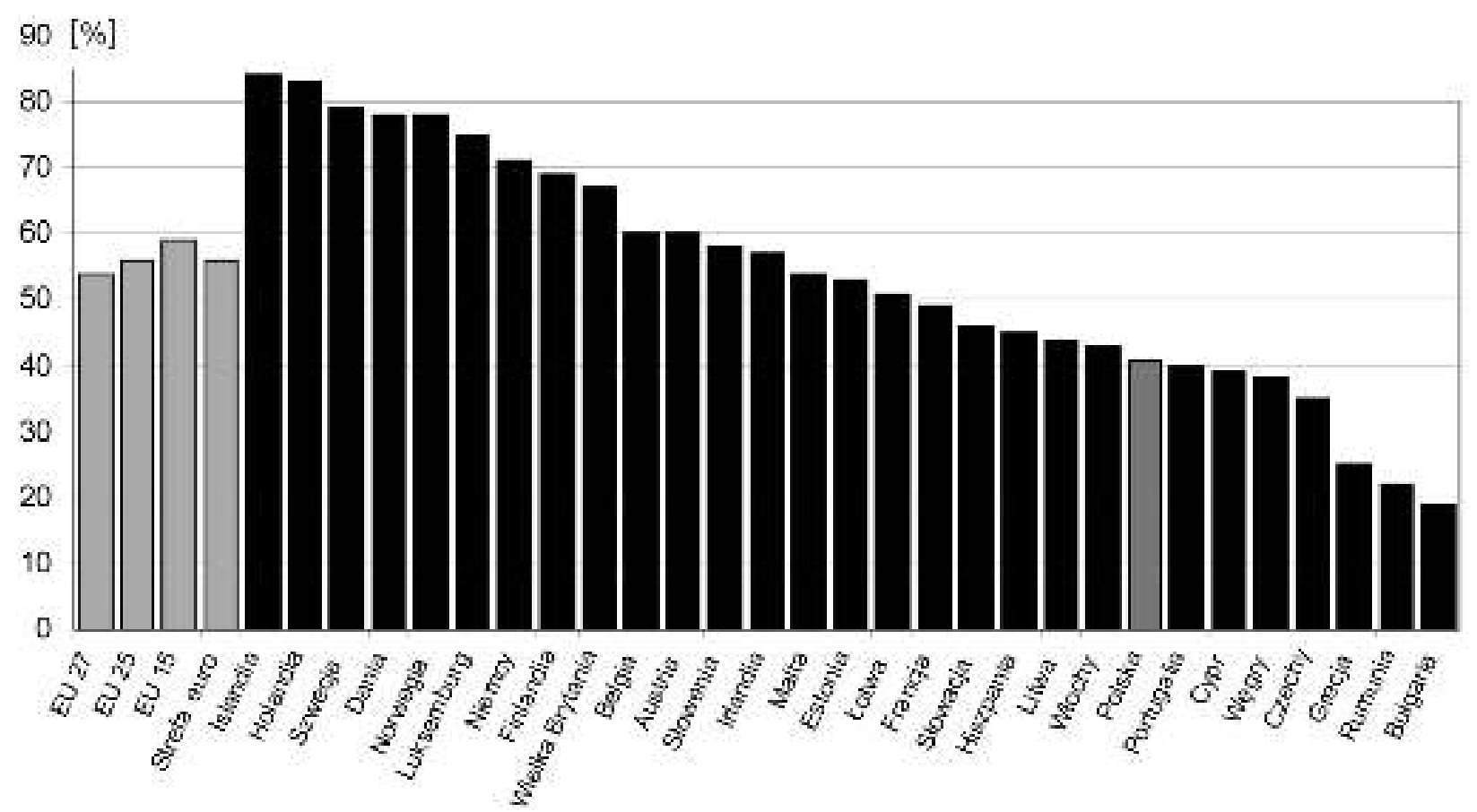

Źródło: opracowanie autorki na podstawie tab. 2.

Podobnie w latach 2004-2007 zwiększył się w UE udział osób korzystających z internetu $\mathrm{w}$ domu - z 32\% do 47\%, czyli o 15 pp. (tab. 2). W latach 2002-2007 największy wzrost zaznaczył się w Luksemburgu (o 40 pp.), Austrii (o 32 pp.), Finlandii (o 29 pp.) i Danii (o 28 pp.), a po rozszerzeniu UE w 2004 r. największy wzrost nastąpił na Łotwie (o 32 pp.), na Litwie (o 28 pp.), na Węgrzech (o 24 pp.). W Polsce w latach 2004-2007 obserwuje się wzrost udziału z $15 \%$ do $33 \%$, czyli o 18 pp.

Ryc. 4. Udział osób w wieku 16-74 lata w ogólnej liczbie ludności korzystającej z internetu w domu w 2007 r.

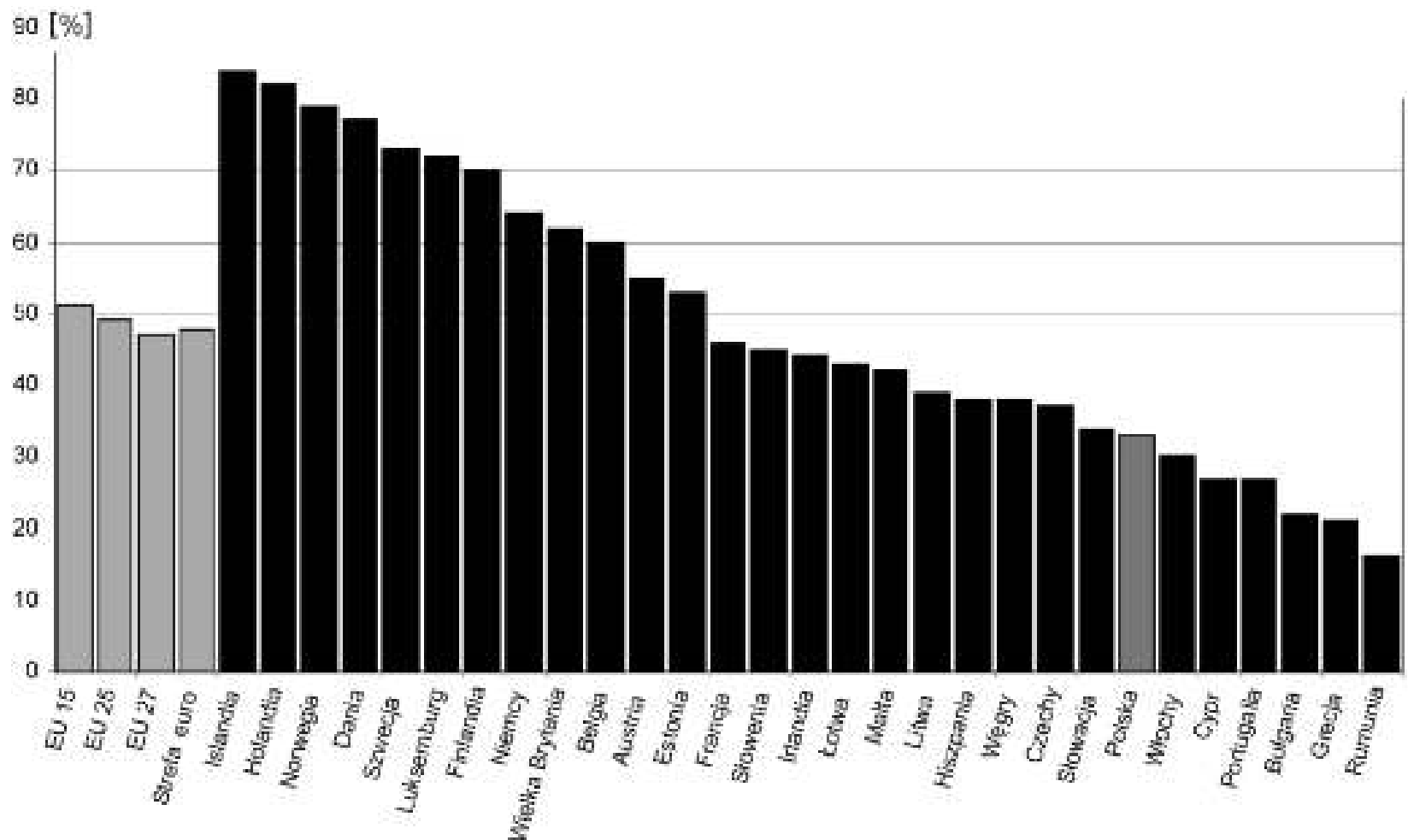

Źródło: opracowanie autorki na podstawie tab. 2. 
W 2007 r. najwyższym udziałem - powyżej 70\% - odznaczają się Islandia, Holandia, Dania, Szwecja, Luksemburg i Finlandia (rys. 4), a najniższym - poniżej 30\% - Rumunia, Grecja, Bułgaria, Portugalia, Cypr i Włochy.

W UE udział osób korzystających z internetu w miejscu edukacji wynosi 8\%. Najwyższym udziałem - powyżej 10\% - odznaczają się: Finlandia, Litwa, Słowacja, Dania, Estonia, Dania, Holandia, Szwecja, Łotwa i Polska (10\%), a najniższym - poniżej 5\% - Malta, Cypr, Grecja, Bułgaria, Rumunia, Włochy i Francja.

W Polsce osoby regularnie korzystające z komputera to głównie osoby młode; w grupie wiekowej 16-24 lat ich udział wynosi aż 83\%, a w grupie wiekowej 65-74 lat - już tylko 3\% (ryc. 5). Wraz ze wzrostem poziomu wykształcenia udział osób korzystających z komputera zwiększa się; wśród osób z wykształceniem podstawowym lub gimnazjalnym wynosi on tylko 34\%, a wśród osób z wykształceniem wyższym - aż 80\%. W zakresie aktywności zawodowej najwyższy udział osób regularnie korzystających z komputera występuje wśród uczniów i studentów (92\%), a najniższy - wśród emerytów i biernych zawodowo (11\%). Najczęściej z komputerów korzystają osoby mieszkające w dużych miastach (55\%). Należy podkreślić, że aż 80\% osób w wieku 16-24 lat w Polsce zdobyło umiejętność posługiwania się komputerem lub internetem w szkole lub na uczelni wyższej.

Ryc. 5. Udział ludności regularnie korzystającej z komputera w Polsce w 2006 r.

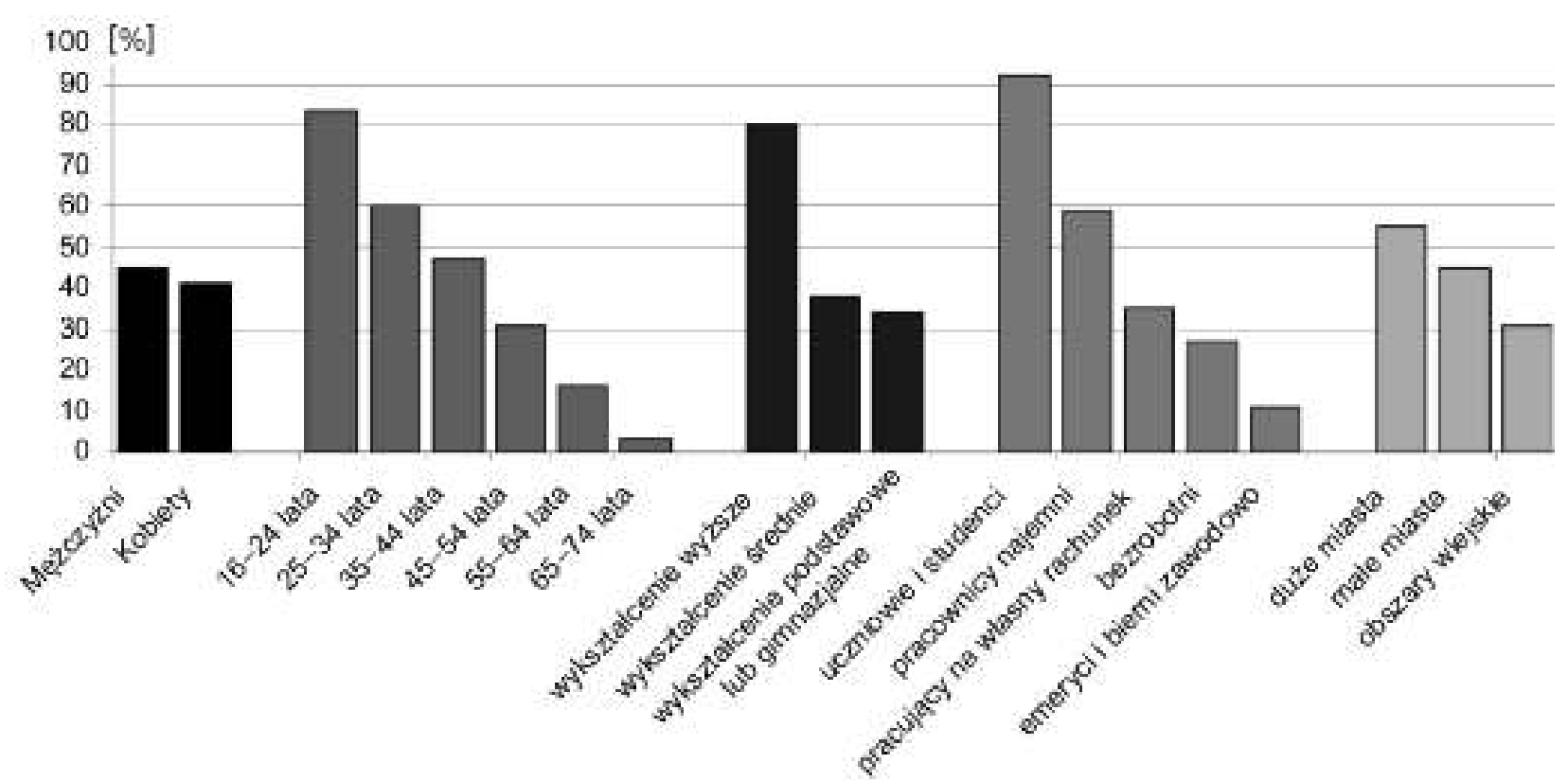

Źródło: opracowanie autorki na podstawie: Społeczeństwo informacyjne w Polsce. Wyniki badań statystycznych z lat 2004-2006, GUS, Warszawa 2008.

W dokumentach dotyczących rozwoju społeczeństwa informacyjnego w Unii Europejskiej, takich jak eEurope, podkreśla się umożliwienie dostępu do internetu uczniów każdego typu szkół. Ponadto wskazuje się na „możliwość korzystania z usług pomocniczych i zasobów szkoleniowych $\mathrm{w}$ internecie oraz systemów elektronicznego nauczania przez nauczycieli, uczniów i rodziców". 2

W Polsce w latach 2002-2006 liczba komputerów w szkołach podstawowych zwiększyła się z 113,5 tys. do 222,5 tys., czyli o 96\%, a średnia liczba komputerów na szkołę - z 7 do 15 , podczas gdy liczba szkół podstawowych zmniejszyła się o 7\% (Społeczeństwo informacyjne

${ }^{2}$ eEurope+ 2003 A co-operative effort to implement the Information Society in Europe, 2001, http://ec.europa.eu/information_society/eeurope/i2010/docs/2002/action_plan/eeurope_2003.pdf 
w Polsce, 2008). W latach 2002-2006 wzrost liczby komputerów przeznaczonych do użytku uczniów był nieco wolniejszy niż w przypadku wszystkich komputerów w szkołach podstawowych, ich liczba zwiększyła się bowiem z 93,1 tys. do 173,5 tys., czyli o 86\%, co oznacza, że udział komputerów do dyspozycji uczniów w ogóle komputerów stanowiących wyposażenie szkół zmniejszył się z $82 \%$ do $78 \%$, czyli o 4 pp. W ostatnich latach nastąpiła poprawa dostępności internetu w szkołach podstawowych. W 2002 r. posiadały one 51,4 tys. komputerów z dostępem do internetu, a w 2006 r. takich komputerów było prawie trzykrotnie więcej - 141,4 tys. W tym okresie wzrosła również liczba komputerów z dostępem szerokopasmowym do internetu - z 37,1 tys. do 84, 5 tys., czyli o 27,8\%.

W latach 2002-2006 liczba komputerów w gimnazjach rosła nieco wolniej niż w szkołach podstawowych; zwiększyła się z 74,1 tys. do 116,9 tys., czyli o 57,8\%, przy wzroście liczby gimnazjów o 7\%. W 2002 r. na jedno gimnazjum przypadało 11 komputerów, a w cztery lata później - 16. Nieco wolniejsze tempo wzrostu liczby komputerów w gimnazjach w stosunku do szkół podstawowych wynika prawdopodobnie z faktu, że gimnazja, jako nowe placówki, od początku swojego istnienia były wyposażane w nowoczesny sprzęt, w związku z czym już w 2002 r. nasycenie komputerami było tam stosunkowo wysokie. W 2002 r. do użytku uczniów gimnazjów przeznaczono 61,9 tys. komputerów, a w 2006 r. niemal o połowę więcej - 91,3 tys. Udział sprzętu do dyspozycji uczniów w ogólnej liczbie komputerów, w które wyposażone są gimnazja, był niemal identyczny jak w szkołach podstawowych. Liczba komputerów z dostępem do internetu zwiększyła się z 54,3 tys. do 86,3 tys., czyli o 58,9\%, wzrastała zatem prawie w takim samym tempie, jak ogólna liczba komputerów w gimnazjach. $\mathrm{O}$ wiele szybsze było tempo wzrostu liczby komputerów z szerokopasmowym dostępem do internetu; tylko w latach 2004-2006 ich stan zwiększył się z 31,2 tys. do 56,7 tys., czyli o 81,7\%. W 2002 r. na jedno gimnazjum przypadało średnio 4,4 komputera z dostępem szerokopasmowym (przy 2,5 na jedną szkołę podstawową), a w 2006 r. -8 (przy niecałych 6 na szkołę podstawową).

W liceach ogólnokształcących również systematycznie zwiększała się liczba komputerów, z 43,6 tys. w 2002 r. do 75,0 tys. w 2006 r., czyli o 72,0\%. Podobnie jak w gimnazjach, w 2002 r. na jedno liceum ogólnokształcące przypadało średnio 11, a w 2006 r. - 16 komputerów. Udział komputerów przeznaczonych do użytku licealistów w stosunku do ogólnej liczby takich urządzeń utrzymywał się na podobnym poziomie jak w szkołach podstawowych i gimnazjach i w 2006 r. wynosił 77\%. W latach 2002-2006 r. liczba komputerów z dostępem do internetu w liceach ogólnokształcących wzrosła ponaddwukrotnie - z 34,3 tys. do 69,1 tys. W 2006 r. aż 92\% wszystkich komputerów w liceach miało dostęp do internetu, a udział komputerów z dostępem szerokopasmowym zwiększył się z 54\% do 62\%, czyli o 8 pp.

W 2004 r. w 427 szkołach wyższych było 66,3 tys. komputerów do użytku studentów, w 2005 r. w 445 uczelniach - 70,4 tys., a w 2006 r. w 448 uczelniach - 78,2 tys. ${ }^{3}$ Na jedną szkołę wyższą w 2006 r. przypadały średnio 174 komputery przeznaczone dla studentów, czyli prawie o 20 więcej niż w 2004 r. W 2006 r. 95\% komputerów uczelnianych miało dostęp do internetu, a 92\% - dostęp szerokopasmowy (rok wcześniej szerokopasmowy dostęp miało $83 \%$ komputerów).

Należy podkreślić, że oprócz zwiększania wyposażenia szkół na wszystkich poziomach edukacji w narzędzia informatyczne i dostęp do internetu istotne jest kształcenie umiejętności obsługi elektronicznych mediów w celu właściwego wykorzystania rozproszonej informacji. Komputery wraz $\mathrm{z}$ nowoczesną technologią posługiwania się informacją stanowią szansę odejścia od encyklopedyzmu i umożliwiają wyrabianie umiejętności ciągłego kształcenia się i radzenia sobie z dużym napływem zasobów informacji (Majta 2003). Ten proces powinien

${ }^{3} \mathrm{~W}$ szkołach wyższych badania wyposażenia w komputery prowadzone są od $2004 \mathrm{r}$. 
dotyczyć nie tylko dzieci i młodzieży szkolnej, ale także dorosłych zmuszonych do zapoznawania się z nowymi technologiami informacyjnymi i komunikacyjnymi. Nowe formy nauczania wspomagające kształcenie ustawiczne (np. e-learning) będą stosowane coraz częściej, ponieważ coraz szybsze tempo zmian wymusza poszukiwanie rozwiązań wygodniejszych i dających zadowalające rezultaty.

W. Abramowicz (2002) przyjmuje, że:

- Obywatel informujący się musi poznać narzędzia teleinformatyczne w sposób pozwalający mu uzyskiwać informacje potrzebne w danym czasie i miejscu, aktualne, wiarygodne oraz przyswajalne, tzn. przekazane $\mathrm{w}$ formie niewymagającej dalszego przetwarzania.

- Obywatel komunikujący się potrafi komunikować się drogą elektroniczną w celach zarówno zawodowych, jak i osobistych, również z przedstawicielami innych kultur.

- Obywatel uczący się pozyskuje wiedzę stanowiącą o jakości jego życia zawodowego i prywatnego, wykorzystując do tego celu narzędzia teleinformatyczne; potrafi określać swoje bieżące i strategiczne potrzeby informacyjne, które może zaspokoić w elektronicznych źródłach wiedzy.

- Obywatel tworzący potrafi tworzyć produkty i usługi cyfrowe służące zaspokajaniu potrzeb innych obywateli.

Oprócz umiejętności posługiwania się narzędziami służącymi do wyszukiwania informacji istotna jest umiejętność formułowania swoich potrzeb informacyjnych. „Motywacja i samomotywacja, a w konsekwencji umiejętność informowania się dzieli społeczeństwo na wiedzące i niewiedzące. Zadaniem szkół jest zatem budzenie ciekawości świata i uczenie sposobów jej zaspokajania, tworząc $\mathrm{w}$ ten sposób stałe nawyki zdobywania i pogłębiania wiedzy" (Abramowicz 2002, s. 124).

Zdobywane w procesie edukacji wiedza i umiejętności coraz szybciej się dezaktualizują i wymagają zdolności do identyfikowania braków w swojej wiedzy oraz sposobów jej pozyskiwania. Ciągle uaktualniana wiedza będzie określać miejsce na rynku pracy. W procesie kształtowania społeczeństwa informacyjnego i gospodarki opartej na wiedzy ważne są również cechy osobowościowe, takie jak kreatywność i - z jednej strony - samodzielność, a z drugiej - umiejętność współpracy z innymi w rozwiązywaniu coraz bardziej złożonych problemów. W procesie edukacji powinno się zatem dążyć nie tylko do opanowania wiedzy, ale i do wyrobienia w sobie zdolności do jej wykorzystywania, do tworzenia nowej wiedzy oraz do pracy zespołowej.

Autor zauważa, że „wiedza konwencjonalna”, dostępna dla wszystkich, będzie warunkiem istnienia na rynku pracy, a warunkiem podnoszenia konkurencyjności na rynku pracy będzie wiedza niekonwencjonalna. Najbardziej niekonwencjonalna jest wiedza twórcy, autor przyjmuje zatem, że system edukacyjny musi nastawić się na wykształcenie u uczniów i studentów oryginalności, co wymaga nowych metod kształcenia i nowego przygotowania nauczycieli.

Wydaje się, że kształtowanie umiejętności, zwłaszcza cech osobowościowych umożliwiających sprawne funkcjonowanie w społeczeństwie informacyjnym, jest bardzo ważne w całym procesie edukacyjnym, ale szczególna rola $\mathrm{w}$ tym zakresie przypada kształceniu z podstaw przedsiębiorczości. $\mathrm{W}$ celu przyspieszenia wkraczania $\mathrm{w}$ informacyjną fazę rozwoju konieczne jest zwiększenie informatyzacji procesu dydaktycznego i upowszechnienie technik multimedialnych środków przekazu, rozwój różnych form kształcenia ustawicznego, zintensyfikowanie na wszystkich poziomach kształcenia języków obcych oraz kształtowanie postaw przedsiębiorczych. 


\section{Literatura}

1. Abramowicz W., Gogołka W., Stokłosa J., Sysło M.M., 2002, Obywatele globalnego społeczeństwa informacyjnego, rozdz. Edukacja [w:] Polska w drodze do globalnego społeczeństwa informacyjnego. Raport o rozwoju społecznym, W. Cellary (red.), Raport przygotowany przez Program Narodów Zjednoczonych ds. Rozwoju (UNDP).

2. Casey M., 2001, Europejska polityka informacyjna. Wyzwania i perspektywy dla administracji publicznej, Międzynarodowe Centrum Zarządzania Informacją Uniwersytetu Mikołaja Kopernika, Toruń.

3. Długosz J., 2003, Społeczeństwo informacyjne a wykluczeni [w:] Biuletyn EBIB, dokument elektroniczny, nr 7/2003 (47) lipiec/sierpień - czasopismo elektroniczne, B. Bednarek-Michalska (red.), Stowarzyszenie Bibliotekarzy Polskich KWE, Warszawa.

4. Goban-Klas T., Sienkiewicz P., 1999, Społeczeństwo informacyjne: Szanse, zagrożenia, wyzwania. Wyd. Fundacji Postępu Telekomunikacji, Kraków.

5. Majta M., 2003, Społeczeństwo informacyjne jako nowa formacja cywilizacyjna (fragment pracy magisterskiej) [w:] Biuletyn EBIB, nr 7/2003 (47) lipiec/sierpień - czasopismo elektroniczne, B. Bednarek-Michalska (red.), Stowarzyszenie Bibliotekarzy Polskich KWE, Warszawa, tryb dostępu: http://ebib.oss.wroc.pl/2003/47/majta1.php.

6. Nowak J. S., 2005, Spoteczeństwo informacyjne - geneza i definicje (dokument elektroniczny).

7. Naisbitt J., 1997, Megatrendy: dziesięć nowych kierunków zmieniających nasze życie, Zysk i S-ka Wydawnictwo, Poznań.

8. Raport Cele i kierunki rozwoju społeczeństwa informacyjnego w Polsce, Ministerstwo Lączności RP, Komitet Badań Naukowych, Warszawa 2000.

9. Społeczeństwo informacyjne w Polsce. Wyniki badań statystycznych z lat 2004-2006, GUS, Warszawa 2008.

\section{The Role of Education in the Development of Information Society}

Fundamental factor of the information society's development is the quality of human capital and the computerization of learning process. The author has emphasized the different meanings of information society as well as and the objectives of its development in Poland. Then the author indicated the differentiation of European countries in terms of an access to the Internet and in numbers of the informatics schools graduates. The author points, out that not only the advancement in the area of the school informatics endowment and access to Internet are important, but also the improvement in the ability to operate the electronic media in order to select and to use the dispersed information. The development of various forms of lifelong learning can be useful in the creation of information society. 